\title{
Trends in Gross Enrolment Ratio of Male Female Enrolment and Expenditure on Higher Education as Percentage of Gross Domestic Product India
}

\author{
M. O. Wankhade
}

\begin{abstract}
Education plays a vital role in development of the society and the nation at large. It prepares and trained staff in any respect levels to manage capital, technology services and administration at each sector within the economy of the nation. India is presently at the stage of demographic transition wherever growth is retardation down however, the population of young people entering the labor/employment force continues to expand.

This young and huge population ought to be educated for the betterment of the state. Gross Enrolment Ratio (GER) in higher education with respect to gender is having increasing trend. The proportion of students enrolling in the higher education has increased significantly during the last two decades and as a result the higher education institutes, private universities, private and government colleges, in India are increasing significantly. Though the government of India has its own limitations towards funding the higher education should formulate the policy of funding to the universities/educational institutes so that the quality and standard in higher education is maintained. The aim of this paper is to study the trends in male, female enrolment and expenditure on higher education as \% of Gross Domestic Product (GDP) of country. The secondary data is taken from the annual reports of University Grants Commission, AISHE and Ministry of Human Resource Development of India. The data is analyzed by using MINITAB19 statistical software by fitting quadratic trend and the forecasts for the period 2018-19 to 2027-28 with respect to GER of Male, Female and public expenditure on higher education in India. The accuracy of the fitted model is measured on the basis of Mean Absolute Percent Error (MAPE). It was observed that student enrolment in higher education is increased but the expenditure on higher education as \% of GDP has sown decreasing trend after 2000-2001.
\end{abstract}

Keywords : GER, Higher Education, Gross Domestic Prodict, Expenditure, Quadratic Trend Analysis.

\section{INTRODUCTION}

Expenditure on higher education is one of the major concerns, and it requires active participation from the government and private bodies to initiate an action against it. The Scientific Manpower Committee[1] and Radhakrishnan committee[2] suggested expansion, quality improvement and financial support from the government.

Revised Manuscript Received on December 30, 2019.

* Correspondence Author

M. O. Wankhade, Associate Professor of Statistics, Dept. of Statistics, G. S. Science, Arts and Commerce College, Khamgaon (MS) 444303 India

(C) The Authors. Published by Blue Eyes Intelligence Engineering and Sciences Publication (BEIESP). This is an open access article under the CC BY-NC-ND license (http://creativecommons.org/licenses/by-nc-nd/4.0/)
The recommendations of these commissions and committees jointly were incorporated in the first three Five Year Plan determinations with quality improvement and expansion of education in India. Punnayya Committee Report on UGC Funding of Institutions of Higher Education [3] (1993) also emphasized that higher education plays vital role for country's economic and technological progress. They suggested that Government funding must continue to support higher education. There are two major players in financing of education in India, firstly public sector and secondly private sector. Financing from public sector includes spending by central government, state government, local bodies and foreign aid which is transferred primarily through central government budgets. During 1956-57, government spending on education sector in India was only Rs 206.31 crores, which include spending of Rs 25.27 crore on higher education and Rs. 7.79 crore on technical education. Government expenditure on education was increased remarkably to Rs 3,374.33 crores out of which expenditure on higher and technical education was increased to 483.66 crore and Rs 136.95 crore respectively during 1980-81. In the period 1990-91, total expenditure on education sector and two of its subsector viz. higher and technical education was Rs. 17193.66 crore, Rs. 2311.85 crore and Rs 753.01 crore[5,6,8]. For the period 2009-10, the amount of government spending has increased to Rs 194642.91 crore, Rs 24831.93 crore and Rs 9469.35 crore[9,10]. During 1990s, budgetary allocations to higher education have been restricted and as a result the higher education sector has suffered badly and led to sharp decline. The public funds have been reduced by many governments capacity to support higher education which resulted into mismatch between demand of higher educational services in the country and its supply. As per UGC annual reports[4] there are 316 private universities in India till December 2018 showing significant increase in educational institutions. The enrollment in private colleges is 64\% as per AISHE report 2014.There are more than $78.0 \%$ colleges running in Private sector; aided and unaided taken together, but it caters to only $67.3 \%$ of the total enrolment. 
Trends in Gross Enrolment Ratio of Male Female Enrolment and Expenditure on Higher Education as Percentage of Gross Domestic Product India

\section{METHODOLOGY}

The secondary data is extracted from the websites of UGC[4,5,6], MHRD for the period 2001-2018[11] and analyzed using MINITAB software. The forecasts are generated for the period 2018-19 to 2027-28.

Quadratic Trend model:

$$
\mathrm{Y}_{\mathrm{t}}=\alpha+\beta \times \mathrm{t}+\gamma \times \mathrm{t}^{2}
$$

Where $\alpha, \beta$ and $\gamma$ are the constants to determined by the method of least squares.

Table-1 The GER of Men and Women in Higher Education

\begin{tabular}{|l|l|l|l|}
\hline Year & $\begin{array}{l}\text { GER } \\
\text { Male }\end{array}$ & $\begin{array}{l}\text { GER } \\
\text { Female }\end{array}$ & $\begin{array}{l}\text { Public Expenditure } \\
\text { on Higher Education } \\
\text { As of GDP }\end{array}$ \\
\hline $2000-01$ & 9.3 & 6.7 & 0.81 \\
\hline $2001-02$ & 10.3 & 7.5 & 0.63 \\
\hline $2002-03$ & 10.6 & 7.7 & 0.69 \\
\hline $2003-04$ & 11.6 & 8.2 & 0.62 \\
\hline $2004-05$ & 13.5 & 9.4 & 0.66 \\
\hline $2005-06$ & 14.5 & 10 & 0.78 \\
\hline $2006-07$ & 15.2 & 10.7 & 0.8 \\
\hline $2007-08$ & 15.8 & 11.4 & 0.83 \\
\hline $2008-09$ & 17.1 & 12.7 & 0.9 \\
\hline $2009-10$ & 20.8 & 17.9 & 0.91 \\
\hline $2010-11$ & 22.1 & 19.4 & 0.95 \\
\hline $2011-12$ & 22.7 & 20.1 & 0.9 \\
\hline $2012-13$ & 23.9 & 22.0 & 0.85 \\
\hline $2013-14$ & 25.3 & 23.2 & 0.67 \\
\hline $2014-15$ & 25.4 & 23.4 & 0.64 \\
\hline $2015-16$ & 25.4 & 23.5 & 0.71 \\
\hline $2016-17$ & 26.0 & 24.5 & 0.77 \\
\hline $2017-18$ & 26.3 & 25.4 & 0.75 \\
\hline Source[11]: Extracted from Educational Statistics at a Glance, Ministry of
\end{tabular}

GER- Gross Enrolment Ratio HRD Reports

ME- Male Enrolment, FE-Female Enrolment

PEHE- Public Expenditure on Higher Education

\section{RESULT AND DISCUSSION}

\section{i. Fitting of the Model}

The Quadratic trend Model fitted for the data are;

Male Enrolment :

$$
\mathrm{Y}_{\mathrm{ME}}=6.658+1.498 \times \mathrm{t}-0.0190 \times \mathrm{t}^{2}
$$

Estimated values of constants;

$\alpha_{1}=6.658$

$\beta_{1}=1.498$

$\gamma_{1}=-0.019$

Female Enrolment :

$\mathrm{Y}_{\mathrm{FE}}=4.19+1.125 \times \mathrm{t}+0.0076 \times \mathrm{t}^{2}$

$\alpha_{2}=4.19$

$\beta_{2}=1.125$

$\gamma_{2}=0.0076$

Public Expenditure on Higher Education:

$\mathrm{Y}_{\mathrm{PEHE}}=0.6024+0.0447 \times \mathrm{t}-0.002189 \times \mathrm{t}^{2}$

$\alpha_{3}=0.6024$

$\beta_{3}=0.0447$

$\gamma_{3}=0.002189$

\section{ii. Measure of Accuracy:}

Retrieval Number: B3349129219/2019@BEIESP a. Mean Absolute percent Error (MAPE)

MAPE $=100 * \frac{1}{n} \sum_{i=1}^{n} \frac{\left|Y_{t}-\widehat{Y}_{t}\right|}{Y_{t}}$

b. Mean Absolute Deviation (MAD)

$\operatorname{MAD}=\frac{1}{\mathrm{n}} \sum_{\mathrm{i}=1}^{\mathrm{n}}\left|\mathrm{Y}_{\mathrm{t}}-\widehat{\mathrm{Y}}_{\mathrm{t}}\right|$

c. Mean Square Deviation (MSD)

$\operatorname{MSD}=\frac{1}{n} \sum_{i=1}^{n}\left|Y_{t}-\widehat{Y}_{t}\right|^{2}$

Where

$\mathrm{n}$ - the number of observations,

$\mathrm{Y}_{\mathrm{t}}$ - observed value

$\hat{\mathrm{Y}}_{\mathrm{t}}$ - Estimated value

Table-2 Accuracy measures

\begin{tabular}{|l|c|c|c|}
\hline $\begin{array}{l}\text { Accuracy } \\
\text { measures }\end{array}$ & ME & FE & PEHE \\
\hline MAPE & 5.2255 & 9.58419 & 9.77645 \\
\hline MAD & 0.88797 & 1.30685 & 0.07263 \\
\hline MSD & 0.9555 & 2.08116 & 0.00754 \\
\hline
\end{tabular}

Table-3 Forecasts Generated

\begin{tabular}{|c|c|c|c|c|}
\hline $\begin{array}{c}\text { Sr. } \\
\text { No }\end{array}$ & Year & $\begin{array}{c}\text { GER } \\
\text { Male }\end{array}$ & $\begin{array}{c}\text { GER } \\
\text { Female }\end{array}$ & $\begin{array}{c}\text { Public } \\
\text { Expenditure on } \\
\text { Higher } \\
\text { Education }\end{array}$ \\
\hline 1 & $2018-19$ & 28.2426 & 28.3010 & 0.661422 \\
\hline 2 & $2019-20$ & 28.9981 & 29.7224 & 0.620746 \\
\hline 3 & $2020-21$ & 29.7155 & 31.1591 & 0.575691 \\
\hline 4 & $2021-22$ & 30.3949 & 32.6110 & 0.526259 \\
\hline 5 & $2022-23$ & 31.0362 & 34.0782 & 0.472448 \\
\hline 6 & $2023-24$ & 31.6394 & 35.5605 & 0.414260 \\
\hline 7 & $2024-25$ & 32.2046 & 37.0581 & 0.351692 \\
\hline 8 & $2025-26$ & 32.7318 & 38.5709 & 0.284747 \\
\hline 9 & $2026-27$ & 33.2209 & 40.0989 & 0.213424 \\
\hline 10 & $2027-28$ & 33.6719 & 41.6422 & 0.137722 \\
\hline
\end{tabular}
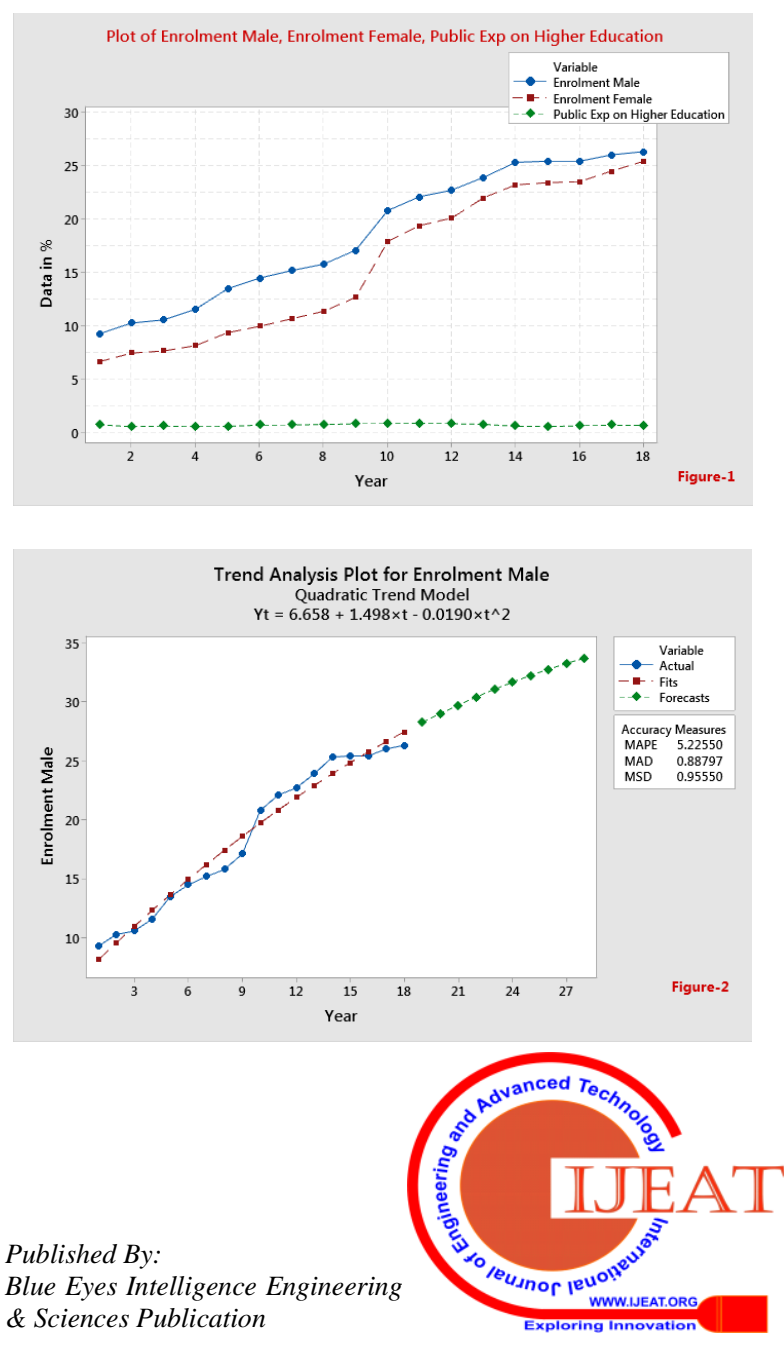

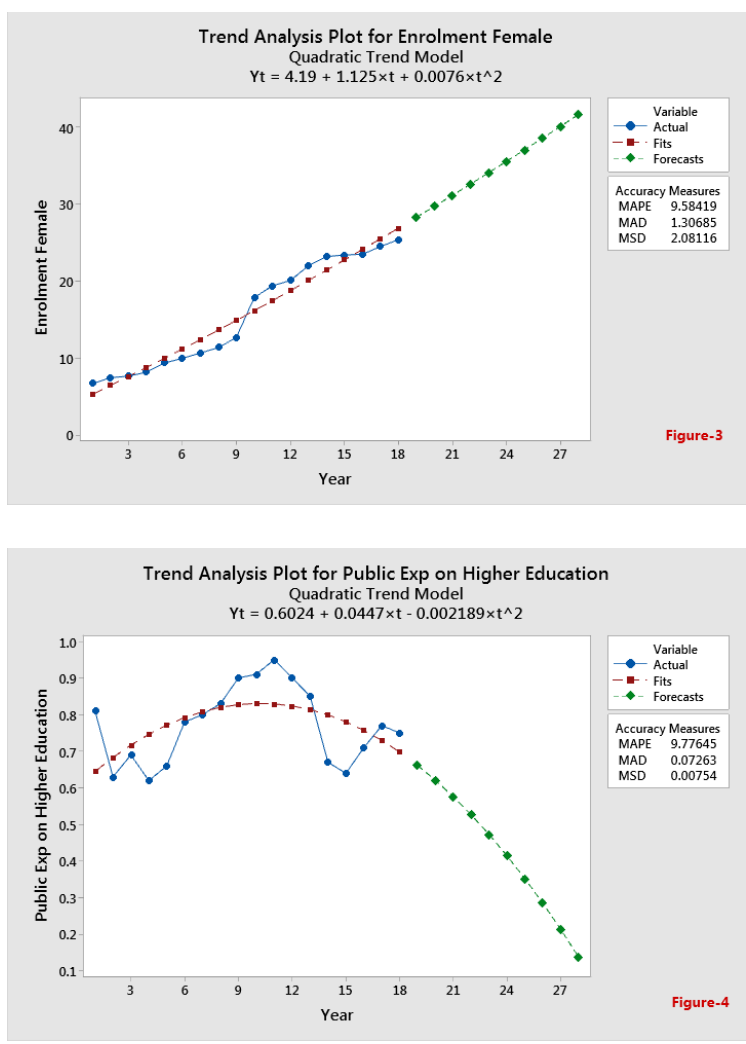

\section{CONCLUSION}

On the basis of mean absolute percent error (MAPE) we observed that quadratic trend model is more accurate for forecasts for the problem under study. Gross enrolment ratio of male and female in higher education is increasing at significant rate (Figure 2 and 3) while the expenditure on the higher education showed decrease (Figure 4). An expenditure on higher education will be decreasing significantly if the same trend continues. An expenditure on higher education will be less than $0.5 \%$ of GDP of India from the year 2022-23 and the model predicts that it will be only $0.13 \%$ of GDP by the period 2027-28. Finally we conclude that the government should increase public funds for higher education and a policy be framed to maintain the quality and standards in higher education in India .

\section{REFERENCES}

1. Scientific Manpower Committee 1947 Report, Ministry of Education Government of India.

2. Indian University Education Commission 1948-49, Dr. Radhakrishnan Committee Report.

3. Report of Justice Dr. J Punnayya Committee UGC Funding of Institutions of Higher Education, 1992-93

4. All India survey on HE , MHRD, 2010-11 to 2017-18

5. Higher Education at Glance, UGC report 2017-18

6. UGC (Establishment of and Maintenance of Standards in Private Universities) Regulations 2003, http://www.ugc.ac.in/policy/regulationspdf/establishment_maintenance .pdf

7. Keertika Lal, Prof. V P S Arora Women Enrolment: Existing Trends In Higher Education International Journal of Enterprise Computing and Business Systems, Volume 6 Issue 2 July - December 2016

8. Ministry of Human Resource Development Government of India, Department of School

9. Education \& Literacy, New Delhi - Education Statistics at a Glance 2016.

10. University Grants Commission Annual Report 2015-16

11. Educational Statistics at a Glance, Ministry of HRD Reports, Government of India.

\section{AUTHORS PROFILE}

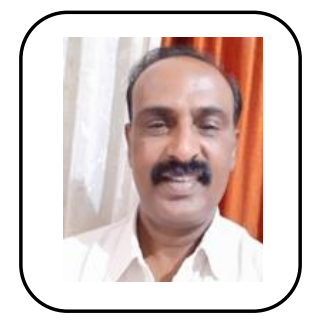

M. O. Wankhade, Qualification: M. Sc. (Statistics), Ph. D., Post Graduate Diploma in Computer Science. Currently working as Associate Professor of Statistics, Dept. of Statistics, G. S. Science, Arts and Commerce College, Khamgaon (MS) 444303 India Teaching Experience 29 Years. Member Board of Studies, Sant Gadge Baba Amravati University, Amravati. Research Publications in National/ International Journals- 10. Paper Presented in National/International Conferences- 05. Area of interest- Optimization, Time Series Analysis. mail: mowankhade289@gmail.com

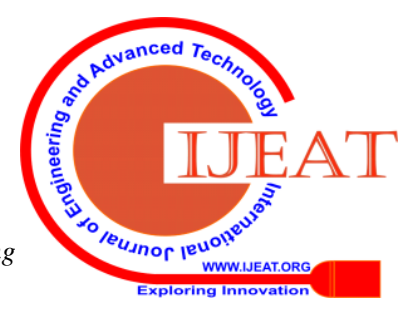

